\title{
Construction Management Service Learning: A "How To" Process for Success
}

\author{
R. Casey Cline, Ph.D. \\ Associate Professor, Department of \\ Construction Management \\ Boise State University \\ Boise, Idaho 83725 \\ ccline@boisestate.edu
}

\author{
Ken Robson \\ Director \& Professor, Haskell \& Irene Lemon \\ Construction Science Division \\ University of Oklahoma \\ krobson@ou.edu
}

\author{
Michael Kroth, Ph.D. \\ Associate Professor, Adult and Organizational Learning \\ University of Idaho \\ Boise, Idaho 83702 \\ mkroth@uidaho.edu
}

\begin{abstract}
To ensure that students are prepared for positions in the construction industry, construction management education programs expose students to industry relevant construction management (CM) theory and practice. Traditional transmission teaching methodologies, while arguably effective for teaching management theory and practice, are not as effective for the transfer of practical leadership skills and knowledge of construction specific processes. As an alternative teaching strategy, many CM programs incorporate service-learning (S-L) into curricula; providing students practical experience, focusing on the acquisition of knowledge through goal setting, thinking, planning, experimentation, observation, and reflection.

However, from a practical standpoint, the development of a service-learning project can be a daunting task for the educator. Beyond determining a suitable project, a great deal of work must be undertaken to ensure a successful learning experience for the learner, as well as a successful project for the project owner or community partner. Processes must be put in place to ensure that the project is well developed, the student is practicing relevant CM skills, the project is completed in a timely manner to the satisfaction of the owner, and that the student learns through active reflection.

Thus, this paper is presented not as a project specific case study, but an attempt to simplify for CM educators the development of CM S-L projects and to provide a step-bystep process to facilitate a successful learning experience.
\end{abstract}

Index Term - Service-Learning, experiential learning, experiential education, community engagement, construction management, construction education.

\section{Introduction}

Construction management $(\mathrm{CM})$ programs attempt to provide students with knowledge and skills required to undertake a management and leadership role in the construction industry. To succeed, students must understand how to manage the complex construction process, requiring an understanding of management theory and practices, an ability to lead a diverse group of skilled 
and non-skilled personnel, and expertise in the construction processes for which he or she is responsible ${ }^{1}$. To foster this educational process many construction management programs use service-learning andralogical processes to combine academic education and "real-world" experience to foster understanding, and to largely broaden the perspective of the CM student. The term andragogy refers to methods or techniques used to educate adults through facilitation, rather than pedagogy, which is generally associated with K-12 instruction ${ }^{2}$. However, managing and performing service-learning projects, e.g. experiential learning (EL) service-learning and/or community engagement (CE) projects, can be a significant challenge, as can making the connection between course material and real life situations and fostering a subjective learning experience achieved through reflection ${ }^{3}$. In fact, the use of experiential education (servicelearning) projects to reinforce classroom content can result in chaotic endeavors that serve as examples of how not to properly manage construction projects ${ }^{4}$.

\section{Service-Learning}

Aristotle said, "For the things we have to learn before we can do them, we learn by doing them." This is true for construction management students because there is a "real-world" gap between construction management theory that students learn during their formal education and the construction management skills that will be required in the field. To allow CM students to "learn the things that they need to learn" many CM programs use service-learning in the form of experiential learning and community engagement projects to foster the "learn by doing" process.

Dewey asserts in his seminal work on service-learning theory, or "theory of experience" that everything occurs within a social environment, and is constructed and based on real-life experiences that provide a context for information being learned ${ }^{5}$. The service-learning model works by exposing the learner to concrete experiences and abstract concepts, and then allowing the learner to use reflective observation and active experimentation to transform the experience ${ }^{6}$. The result of the combination of exposure to the experience and the transformation of the experience is knowledge.

Service-learning can allow for a direct encounter with a subject being studied rather than merely thinking about the encounter. It is a sort of learning that gives students a chance to acquire and apply knowledge, skills and feelings in an immediate and relevant setting ${ }^{7}$. This acquired and applied component is important because too many times education becomes an exercise in dispassionate analysis and instruction trapped within the classroom ${ }^{8}$. Learners need to test the knowledge they have received in the classroom and apply it to the real world, validating their own assumptions about what they have learned. The service-learning process facilitates changes in behavior that are the result of reinforced experience or practice. The change in behavior may or may not occur immediately, but individuals involved in the service-learning process are capable of performing in a way that they could not before being involved in the learning experience? .

Types of service-learning in CM programs usually include active learning (AL), collaborative learning (CL), and problem-based learning (PBL) methodologies. Active learning is an experiential form of learning that requires the learner to engage in meaningful learning activities $^{10}$. AL engages students in activities that force them to reflect upon ideas and how they are using those ideas. Students regularly assess their own degree of understanding and skill at handling concepts and/or problems, and then attain knowledge by participating or contributing. It is a process that keeps students mentally, and often physically, active in their learning through 
activities that involve them in information gathering, thinking and problem solving ${ }^{11}$. Collaborative learning adds a component to the active learning process that requires the learner to work in a group towards a common goal, allowing two or more people to learn or attempt to learn something together ${ }^{12}$. Problem-based learning requires the learner to work on "real-world" problems that are used to provide a realistic context. PBL is initiated by a posed problem, query, or puzzle that the learner wants to solve ${ }^{13}$ and focuses on having students define, research, and solve realistic problems.

\section{Service-Learning Challenges}

Many construction educators believe a "real world" education is imperative in order to ensure students are well equipped to manage the responsibilities of the positions they will eventually hold ${ }^{1}$. Many CM programs believe that construction management education should be approached using established academic disciplines ${ }^{14}$. However, deviating from traditional educational methodologies is not without risk. Some faculty with a traditional engineering education may characterize service-learning as "touchy-feely", stigmatizing the methodology as unintellectual, unsubstantial, and lacking rigorous scholarship ${ }^{15}$. Others question how experiential education differs from learning that occurs through homework assignments and laboratories ${ }^{10}$ and view it as another in a long line of educational fads.

Support for service-learning methodologies is crucial to its success, but garnering this support can be difficult. Many universities espouse the need of service-learning through servicelearning and community engagement projects but falter when the university is exposed to liability due to the elevated risk of construction projects. Additional challenges arise when service-learning projects receive exposure to the public. While public recognition of projects can be beneficial, CM programs active in service-learning risk being associated with vocational/technical programs ${ }^{16}$.

\section{Project Selection}

Service-learning in construction management curricula can be invaluable for reinforcing construction management skills presented in CM coursework. However, service-learning projects take a great deal of effort by the CM educator, and should not be undertaken without prior preparation. Paramount to the success of a service-learning project is to evaluate the feasibility of potential projects. Critical to the project evaluation process is a thorough investigation into the size, comprehensiveness, and complexity of the project. The size of the project is important because it needs to be large enough to allow each CM learner to put forth meaningful effort that reinforces management processes taught in the classroom but small enough to be manageable. Similar is the need for the project to be comprehensive enough to allow students to practice skills learned in construction management coursework, while not so complex, including both the management and labor requirements, that the project is not congruent with the abilities of the student.

The project timeline also needs to be evaluated to determine if the S-L project can be accomplished within the time constraints of the specific $\mathrm{CM}$ course or whether alternative or additional time will be required. Last in the project selection evaluation process is a review of the assessment and reflection components of the project. Does the project allow for set educational 
objectives and goals to be assessed, and will students have a significant enough learning experience that reflection will be valuable ${ }^{1}$.

Over ten years of practice performing construction management service-learning projects, some with less than desirable results, has allowed the primary author the opportunity to develop through trial and error a project management process that has resulted both in successful servicelearning projects and reinforcement of $\mathrm{CM}$ formal education, which is described next. The purpose of the process is to foster the success of CM service-learning projects while at the same time to effectively facilitate a student's mastery of the knowledge, skills, and competencies necessary for success in the construction management field.

\section{Service-Learning Project Process}

Once a project has been identified, evaluated, and selected, students would be assigned to the project. Pure construction management projects may require students to assume the roles of project managers and project engineers. Projects that include a hands-on construction component may require students to undertake superintendent and assistant superintendent roles. The number of students selected for the project is dependent upon the comprehensiveness, complexity, and size of the S-L project as well as the experience of the student participants. A project with a large scope of work may need to be broken into smaller sub-projects to reduce complexity and facilitate the management process.

To facilitate the preconstruction process it is suggested that a standard form electronic documentation system and a standard form hard copy documentation system be developed. Developing an electronic file set and a hardcopy notebook set with ordered sections and requirements will not only give the student a sample of deliverables, but it will facilitate the instructor review process and ensure that items on the project are less likely to be missed. Ordered sections for a hardcopy notebook template would include:

(1) Project Properties (Address and Site Map)

(2) Project Participants (Including Contact Information)

(3) Project Scope and Contract

(4) Project Drawings

(5) Project Specifications

(6) Project Schedule

(7) Project Estimate and Takeoff

(8) Job Cost Detail Report (JCDR)

(9) Material, and Tool and Equipment Lists

(10) Safety Plan and Job Hazard Analysis.

(11) Quality Assurance / Quality Control Plan (QA/QC)

(12) Tool Box Safety Meeting and Site Safety Inspections

(13) QA/QC Checklists

(14) Daily Reports and Time Cards

(15) Correspondence Log (Including Phone and E-mail)

(16) Project Post-Mortem

(17) Project Photos 
Similar to traditional construction management practices, S-L project process can be broken into three phases; pre-construction, construction, and post construction. Each phase has requirements to be met within a set time period designated as milestone deliverables. However, S-L projects have some specific practices that differ from the typical project management system.

\section{Pre-Construction}

Thorough preliminary project development is crucial to a successful project. Students should meet with the project owner(s) to determine the preliminary scope, desired timeline, approximate budget limits, and participants in the project. Information gathered by the students would then be used to develop the preliminary scope, drawings, specification, estimate, and schedule for the project. These items would be submitted to the owner and instructor for final review and approval. Due to the lack of experience by the student in developing preconstruction documents and the CM learning component, careful review and coordination with the owner, instructor, and student is recommended.

Once approved by the owner and instructor, the project final documents are developed, including a final "Scope and Contract", "Drawings", "Specifications", "Estimate", and baseline "Schedule". A detailed review of these items by the instructor is critical to ensure the items are complete and realistic. Once the initial documents are developed and approved, a "Material List" and "Tool and Equipment List" would be developed to ensure that the students have a well thought out plan for the project. The two lists, along with the project estimate should then be converted into a Job Cost Detail Report (JCDR) that can be used to document costs and forecast deviations from the budget. A "Safety Plan and Job Hazard Analysis" would be developed that included a list of safety rules and their applicable OSHA standards that will come into play on the project. A "QA/QC Plan" would be developed for the project that includes a list of standards required by law and/or industry standards applicable to the project. Once these pre-construction items are developed and meet the approval of the instructor, students would then be permitted to begin the actual construction process. Again, though these steps are similar to traditional construction management practices, the lack of experience by the student in developing preconstruction documents and the $\mathrm{CM}$ learning component require careful review and coordination with the owner, instructor, and student.

\section{Construction}

Not all service-learning construction projects require students to self-perform construction activities on projects. If students are managing the project in lieu of self- performing work there will be a greater focus on the management of third party groups and less self-perform focused documentation.

Self-performed projects should begin with the student performing at the beginning of every workday a "Tool Box Safety Talk". The safety topic, special instructions, and names of the safety talk attendees should be documented. The safety talk is especially important when students with little construction experience will be performing hands-on activities. "Site Safety Inspections" should also be conducted daily to ensure that a safe worksite is being provided for all individuals on the jobsite. In addition to the safety talk and inspection, "QA/QC Inspection" should be performed daily to ensure that the project conforms to the project requirements. 
On either self-perform or pure management projects, the student may be responsible for the procuring and expediting materials needed for the project. This would be completed in coordination with the instructor and the project owner. The student should document all project expenditures using a Job Cost Detail Report and update this form at least weekly. The JCDR would also be used in conjunction with a "Daily Time Card" system if tracking student time were required. JCDR documentation evaluation by the instructor allows for the monitoring of expenditures to ensure that the project is within close approximation to the estimate and that there are no improper purchases. The "Daily Report" along with the time card system allows the instructor to gauge progress of the project and the student involvement. Further, the Daily Report can be used for S-L reflection by the student, allowing for the documenting of learning experiences and providing an opportunity for dialogue between the instructor and learner.

\section{Post-Construction}

Upon completion of the project students should develop a "Project Post-Mortem" to give insight as to the positive and negative aspects of the project, and to allow the student to reflect on the construction processes and the personal lessons learned. Reflection is one of the basic requirements of service-learning and can be accomplished in both an academic setting through open discussion or in written forms. Reflection facilitates the learning process by linking abstract concepts taught in the classroom to relevant personal experiences through introspection and selfexpression". The "Project Post Mortem" report would include a narrative of the overall project, a narrative of what went as planned and what did not go as planned, opportunities for improvement, an overall assessment of the estimate and schedule, and learning objectives achieved on the project.

\section{Conclusions}

Service-learning in construction management curricula can be an invaluable tool for reinforcing construction management skills presented in CM courses because it allows the learner to practice those skills in a "real world" setting. Service-learning allows the learner to learn beyond the walls of a classroom by establishing a learning environment best suited for learners to gain knowledge. However, CM service-learning projects require a significant time commitment from both the student and the instructor, both in and outside of the classroom, thus the process should not be undertaken without prior preparation ${ }^{1}$.

Paramount to the success of a service-learning project is the determination of projectspecific criteria to evaluate the feasibility of potential projects. The comprehensiveness, complexity, size, and timeline of the potential service-learning project must be assessed to ensure the project can be successfully completed. In addition, project recipient collaboration, reflection, and evaluation components must be assessed to ensure that the educational components of the SL project are acceptable ${ }^{1}$. If these parameters are not met, the project must not be pursued as part of a CM course.

Continuous monitoring of the project, communication with the student, and communication with the owner is paramount. Documentation of the pre-construction, construction, and postconstruction process is critical to the success of the project and in the assessment of the student learning. 
Although a powerful learning process, the practice of using service-learning projects in CM curricula can be challenging due to logistical concerns, course time and other constraints. Therefore it is imperative for the instructor of CM courses to thoroughly evaluate potential S-L projects to ensure that the project has a high potential for success given the parameters of the specific course. It is also important to remember that success on a service-learning project is not only measured by the successful completion of the project, the accuracy of the schedule, estimate, and owner satisfaction. It is also measured by evaluating the successful achievement of the educational objectives through reflection, student / instructor project examination, and the project post-mortem review. A successful project completion is but one of the goals of a servicelearning class, achievement of the learning objectives is equally important.

\section{REFERENCES}

1 Cline, R. C. (2008). "Teaching key competencies of effect project managers to adults in higher education.” Ph.D. dissertation, University of Idaho, Moscow, ID.

2 Knowles, M. (1988). The modern practice of adult education: from pedagogy to andragogy. Englewood Cliffs, N.J., Cambridge Adult Education.

3 Godfrey, P. C. (1999). Service-learning and management education: A call to action Journal of Management Inquiry, 8(4), 363-378.

${ }^{4}$ Cline, R. C., \& Kroth, M. (2008). The challenges of using service learning in construction management curricula. International Journal for Service Learning in Engineering, 3(1), 1-8.

5 Dewey, J. (1938). Education and experience, Simon and Schuster, New York.Godfrey, P. C. (1999). Service-learning and management education: A call to action Journal of Management Inquiry, 8(4), 363-378.

6 Kolb, D. A., Boyatzis, R. E., \& Mainemelis, C. (2000). Experiential learning theory: Previous research and new directions. In R. J. Sternberg\&L. F. Zhang (Eds.), Perspectives on cognitive, learning, and thinking styles (pp. 227-247). Mahwah, NJ: Lawrence Erlbaum.

7 Brookfield, S. D. (1983) Adult Learning, Adult Education and the Community Milton Keynes Open University Press.

8 Falbo, M. C. (1996). Serving to learn: a faculty guide to service learning. Ohio campus compact, 1996; 41.

9 Kimble, G. (1961). Hilgard and Marquis' conditioning and learning, 2nd ed., Prentice-Hall, Englewood Cliffs, N.J.

10 Prince, M. (2004). "Does active learning work? A review of the research." Journal of Engineering Education, 93(3), 223-231.

11 Greenwood, D., \& Levin, M. (2000). Reconstructing the relationships between universities and society through action research. In N. Denzin \& Y. Lincoln (Eds.), Handbook of qualitative research (2nd ed., pp. 85-106). Thousand Oaks, CA: Sage.

12 Dillenbourg P. (1999). What do you mean by collaborative learning? In P. Dillenbourg (Ed). Collaborative-learning: Cognitive and Computational Approaches. (pp.1-19). Oxford: Elsevier

13 Duch, B.J., Groh, S.E., and Allen, D.E. 2001. The Power of Problem-based Learning. Stirling, VA: Stylus.

14 Hughes, W. (1994) The PhD in construction management. In: 10th Annual ARCOM conference, 14-16 September 1994, Loughborough University, pp. 76-87. 
15 Hessler, H. B. (2000). "Composing an institutional identity: The terms of community service in higher education." Language and Learning Across the Disciplines, 4(3), 27-42.

16 Davis, K. A. \& Cline, R. C. (2009). "Improving course comprehension through experiential learning" in Building a sustainable future: proceedings of the 2009 Construction Research Congress, April 5-7, 2009, Seattle, Washington (0-7844-1020-8, 978-0-7844-1020-2), (p. 1409). Reston, VA: American Society of Civil Engineers.

17 Hampton, S. E., \& Morrow, C. (2003). Reflective journaling and assessment. Journal of Professional Issues in Engineering Education and Practice, 129(ASCE), 186. 